\title{
THE EFFECTIVENESS OF CHRONOTHERAPY IN HYPERTENSIVE PATIENTS WITH AN INSUFFICIENT DEGREE OF SLEEP-TIME DIASTOLIC BLOOD PRESSURE
}

\author{
Kanishcheva O. V., Yabluchansky M. I., Litvin A.S.
}

V. N. Karazin Kharkiv National University, Kharkiv, Ukraine

The violation of daily blood pressure (BP) profile is one of the predictors of cardiovascular (CV) morbidity and mortality in patients with arterial hypertension (AH). It is determined by ambulatory BP monitoring (ABPM). The aim of the study was to assess the impact of the chronotherapeutic approach on the level of systolic blood pressure (SBP) and diastolic blood pressure (DPB) and daily BP profile in patients with AH with insufficient degree of sleep-time relative DBP decline. The study included 28 patients with AH with nondipper DBP daily profile in age from 52 to 78 years old. The participants were divided onto two groups. Group 1 included 14 patients, who take all antihypertensive drugs in the morning, group 2 included 14 patients who take at least one antihypertensive drug at bedtime. All patients underwent 24-hour blood pressure monitoring using the computer system «Cardiosens» (KhAI Medica, Ukraine, with the oscillometric method of BP measurement) when enrolling in the study and after 3 months. The type of SBP and DBP diurnal profile, the mean values of SBP, DBP and hyperbaric indices were determined and compared between groups 1 and 2 at each visit, as well as within groups between visits. The results showed that morning taking of antihypertensive drugs in patients with AH with insufficient degree of DBP decline influences more on SBP while evening taking - on DBP. It was concluded that violation of DBP daily profile in medication therapy of patients with insufficient degree of DBP decline should be provided along with violation of SBP daily profile.

KEY WORDS: arterial hypertension, chronotherapy, diastolic blood pressure, nondipper

\section{ЕФЕКТИВНІСТЬ ХРОНОТЕРАПИИ ГІПЕРТОНІЧНОЇ ХВОРОБИ У ПАЦІЕНТІВ 3 НЕДОСТАТНІМ СТУПЕНЕМ НІЧНОГО ЗНИЖЕННЯ ДІАСТОЛІЧНОГО АРТЕРІАЛЬНОГО ТИСКУ}

Каніщева О. В., Яблучанський М. І., Літвін А. С.

Харківський національний університет імені В. Н. Каразіна, м. Харків, Україна

Порушення добового профілю артеріального тиску (АТ) є одним з факторів ризику серцевосудинної (СС) захворюваності та смертності у пацієнтів 3 артеріальною гіпертензією (АГ) i визначається методом добового моніторування АТ (ДМАТ). Метою дослідження було оцінити вплив хронотерапевтичного підходу на рівень САТ і ДАТ та добовий профіль АТ у пацієнтів з АГ з недостатнім ступенем нічного зниження ДАТ. У дослідження увійшли 28 пацієнтів з АГ з типом добового профілю ДАТ нондіпер у віці від 52 до 78 років. Учасники були розділені на дві групи. До групи 1 увійшли 14 пацієнтів, що приймають все гіпотензивні препарати вранці, в групу 2 14 пацієнтів, що приймають хоча б один гіпотензивний препарат на ніч. Всім пацієнтам проводилося добове моніторування АТ з використанням комп'ютерної системи «Кардіосенс» (XAI Медика, Україна, з осцилометричним методом вимірювання артеріального тиску) при включенні в дослідження і через 3 міс. Визначали тип добового профілю САТ і ДАТ, середні значення САТ, ДАТ і показників навантаження підвищеним тиском і порівнювали між собою в групах 1 та 2 на кожному візиті, а також всередині груп між візитами. Результати показали, що ранковий прийом гіпотензивних препаратів у пацієнтів з АГ з недостатнім ступенем нічного зниження ДАТ в більшій мірі впливає на САТ, а вечірній - на ДАТ. Були зроблені висновки, що в медикаментозної терапії пацієнтів з АГ з недостатнім ступенем нічного зниження ДАТ оцінка його добового профілю повинна проводитися нарівні 3 добовим профілем САТ.

КЛЮЧОВІ СЛОВА: артеріальна гіпертензія, хронотерапия, діастолічний артеріальний тиск, нондіпер 


\section{ЭФФЕКТИВНОСТЬ ХРОНОТЕРАПИИ ГИПЕРТОНИЧЕСКОЙ БОЛЕЗНИ У ПАЦИЕНТОВ С НЕДОСТАТОЧНОЙ СТЕПЕНЬЮ НОЧНОГО СНИЖЕНИЯ ДИАСТОЛИЧЕСКОГО АРТЕРИАЛЬНОГО ДАВЛЕНИЯ}

Канищева Е. В., Яблучанский Н. И., Литвин А. С.

Харьковский национальный университет имени В. Н. Каразина, г. Харьков, Украина

Нарушение суточного профиля артериального давления (АД) является одним из предикторов сердечнососудистой (CC) заболеваемости и смертности у пациентов с артериальной гипертензией (АГ) и определяется методом суточного мониторирования АД (СМАД). Целью исследования было оценить влияние хронотерапевтического подхода на уровень САД и ДАД и суточный профиль АД у пациентов с АГ с недостаточной степенью ночного снижения ДАД. В исследование вошли 28 пациентов с АГ с типом суточного профиля ДАД нондиппер в возрасте от 52 до 78 лет. Участники были разделены на две группы. В группу 1 вошли 14 пациентов, принимающие все гипотензивные препараты утром, в группу $2-14$ пациентов, принимающие хотя бы один гипотензивный препарат на ночь. Всем пациентам проводилось суточное мониторирование АД с использованием компьютерной системы «Кардиосенс» (ХАИ Медика, Украина, с осциллометрическим методом измерения АД) при включении в исследование и через 3 мес. Определяли тип суточного профиля САД и ДАД, средние значения САД, ДАД и показателей нагрузки повышенным давлением и сравнивали между собой в группах 1 и 2 на каждом визите, а также внутри групп между визитами. Результаты показали, что утренний приём гипотензивных препаратов у пациентов с АГ с недостаточной степенью ночного снижения ДАД в большей степени оказывает влияние на САД, а вечерний - на ДАД. Были сделаны выводы, что в медикаментозной терапии пациентов с АГ с недостаточной степенью ночного снижения ДАД оценка его суточного профиля должна проводиться наравне с суточным профилем САД.

КЛЮЧЕВЫЕ СЛОВА: артериальная гипертензия, хронотерапия, диастолическое артериальное давление, нондиппер

\section{INTRODUCTION}

The violation of daily blood pressure (BP) profile is one of the predictors of cardiovascular (CV) morbidity and mortality in patients with arterial hypertension (AH) [1-3] and it is determined by ambulatory BP monitoring (ABPM). Systolic BP (SBP) is ordinarily used as $\mathrm{ABPM}$ index which determines the daily $\mathrm{BP}$ profile $[4,5]$. Diastolic BP (DBP) is considered as a less important parameter despite the fact that in comparison with SBP it is regulated by the other mechanisms and that is why it has its independent prognostic and diagnostic value [6-8].

In one of our previous researches dedicated to study of daily BP profile in patients with unsatisfactory nocturnal SBP decrease it was proved that SBP and DBP profiles vary differently to each other [9]. This fact required a similar study in hypertensive patients with insufficient degree of sleep-time relative DBP decline.

\section{OBJECTIVE}

To assess the impact of the chronotherapeutic approach on the level of SBP and DPB and daily BP profile in patients with $\mathrm{AH}$ with insufficient degree of sleep-time relative DBP decline.

\section{MATERIALS AND METHODS}

The research was carried out within the framework of the research work «Pharmacological and interventional approaches to the treatment of patients with cardiac arrhythmias, arterial hypertension», state registration number 0116 U000973.

In the settings of the outpatient clinic No. 24 in Kharkiv, 44 patients with $\mathrm{AH}$ aged from 41 to 78 years were examined. For further analysis, patients with an insufficient degree of sleeptime relative DBP decline $(<10 \%)$ according to $\mathrm{ABPM}$ were selected.

The study included 28 people with the «nondipper» type of DBP daily profile 19 women (68\%) and 9 men (32\%). The first stage of $\mathrm{AH}$ was diagnosed in 2 patients $(7 \%)$, the second - in $21(75 \%)$, the third - in 5 $(18 \%)$. The first degree of $\mathrm{AH}$ was diagnosed in 13 patients $(46 \%)$, the second - in 6 (21\%). Six patients $(21 \%)$ had controlled AH, with preserving the target values of SBP and DBP throughout the 24 hours. Nocturnal hypertension was diagnosed in 22 cases ( $79 \%$ ).

Participants were divided into two groups. Group 1 included 14 patients taking all antihypertensive drugs in the morning; group 2 included 14 patients taking at least one antihypertensive drug at bedtime. To achieve 
target BP levels, patients, if necessary, underwent correction of antihypertensive therapy - increasing the dose, replacing or adding drugs. The regimen of antihypertensive drugs intake was not changed.

Exclusion criteria were secondary arterial hypertension, hemodynamically significant valvular heart disease, cardiomyopathy of any origin, chronic heart failure of III clinical stage or IV functional class by NYHA, any acute conditions (infections, trauma, operations) during the previous 3 months, chronic diseases in decompensated stage or exacerbation, oncological diseases, as well as any circumstances that make it difficult to perform ABPM.

All patients underwent ABPM when included in the study - 1 visit, and after 3 months -2 visit. The monitoring was carried out using the computer system «Cardiosens» (KhAI Medica, Ukraine) with an oscillometric method of BP measurement. The monitoring was performed in the conditions of a typical patient day, with the preservation of domestic physical and psychoemotional loads. The cuff was placed on the non-dominant hand. According to Ambulatory Blood Pressure Monitoring International Recommendations 2013 [10], BP was measured with an interval of 15 minutes during the period of awake and 30 minutes during the sleep time. Periods of the day and night was defined on the basis of the patient's diary. When assessing ABPM data, in accordance with Ambulatory Blood Pressure Monitoring International Recommendations 2013 [10], manual data extraction was performed - the following measurements were excluded from the analysis:

- $\mathrm{SBP}>250$ or $<70 \mathrm{~mm} \mathrm{Hg}$,

- DBP $>150$ or $<40 \mathrm{~mm} \mathrm{Hg}$,

- pulse pressure $>150$ or $<20 \mathrm{~mm} \mathrm{Hg}$;

- heart rate $>200$ or $<20$ per minute.

The results of ABPM were excluded from analysis in the following cases:

$-\geq 30 \%$ of invalid measurements,

- absence of BP measurements for 2 hours or more,

- unusual daily activity for the patient during monitoring,

- a night sleep period of less than 6 or more than 12 hours [10].

The degree of relative sleep-time BP decline was calculated using the formula:
$(100 \times[$ mean awake BP - mean asleep BP] / mean awake $B P)$.

Depending on the value of this ratio the following types of daily $\mathrm{BP}$ profile were defined:

«dipper» - physiological decrease in BP during the night - sleep-time relative BP decline $10-20 \%$;

«overdipper» - an excessive fall in $\mathrm{BP}$ at night, sleep-time relative BP decline $>20 \%$;

«nondipper» - the lack of BP reduction at night, sleep-time relative BP decline $<10 \%$;

«night-peaker» - night-time BP more than during daily activity, sleep-time relative BP decline $<0$ [4].

The mean values of SBP, DBP and hyperbaric indices for SBP and DBP were determined for 24 hours and periods of day and night and compared in groups 1 and 2 at each visit, as well as within groups between visits.

For each ABPM parameter the arithmetic mean $(\mathrm{M})$, the median $(\mathrm{Me})$, and the standard deviation (Sd) were determined. Proportions of types of the daily BP profile were determined in percent $(\mathrm{P})$.

A comparison of the data obtained in groups 1 and 2 at each stage of the study was performed using the unpaired Student's t-test for parameters with normal distribution and the Mann-Whitney U-test for free-distributed parameters. To compare the proportions the angular transformation method with F-test was used.

\section{RESULTS AND DISCUSSION}

The mean major values of ABMP in patients with insufficient degree of DBP decline in groups 1 and 2 on inclusion into the study are represented in table 1. At the first visit, the mean sleep-time values of SBP and DBP exceeded the recommended threshold levels in both groups during all periods of monitoring. The awake, sleep-time and daily mean values of the SBP and DBP time index (TI) were higher than normal in both groups. The percentages of controlled AH were $29 \%$ in group 1 and $14 \%$ in group 2 respectively (tab. 2). The high percent of nocturnal hypertension was observed in both groups (tab. 2). The daily profile of SBP and DBP in all patients from both groups corresponded to nondipper type. The comparison of studied indexes of ABMP at day time, night time and daily did not reveal significant differences between the groups (tab. 1). 
Table 1

ABPM indices in patients with insufficient degree of DBP decline in groups 1 and 2, visit 1

\begin{tabular}{|c|c|c|c|c|c|c|c|}
\hline \multirow{3}{*}{$\begin{array}{l}\text { Monitoring } \\
\text { periods }\end{array}$} & \multirow{3}{*}{ ABPM indices } & \multicolumn{6}{|c|}{ Patients groups } \\
\hline & & \multicolumn{3}{|c|}{ group 1} & \multicolumn{3}{|c|}{ group 2} \\
\hline & & $\mathbf{M}$ & Me & Sd & $\mathbf{M}$ & Me & Sd \\
\hline \multirow[t]{6}{*}{24 hours } & SBP, mm Hg & 134 & 124 & 24.5 & 138 & 139 & 15.7 \\
\hline & DBP, mm Hg & 76 & 73 & 11.6 & 81 & 80 & 11.6 \\
\hline & SBP TI, \% & 43 & 29 & 34.2 & 62 & 69 & 31.3 \\
\hline & DBP TI, \% & 34 & 26 & 30.9 & 46 & 40 & 33.7 \\
\hline & SBP HBI, mm Hg / h & 236 & 61 & 409.7 & 299 & 267 & 238.7 \\
\hline & DBP HBI, mm Hg / h & 100 & 46 & 139.8 & 158 & 126 & 159.9 \\
\hline \multirow[t]{6}{*}{ Awake } & SBP, mm Hg & 135 & 125 & 25.4 & 139 & 139 & 16.4 \\
\hline & DBP, $\mathbf{m m ~ H g}$ & 77 & 75 & 11.9 & 82 & 80 & 11.8 \\
\hline & SBP TI, \% & 37 & 18 & 36.6 & 55 & 59 & 35.3 \\
\hline & DBP TI, \% & 26 & 12 & 31.6 & 39 & 34 & 35.2 \\
\hline & SBP HBI, mm Hg / h & 139 & 19 & 267.5 & 166 & 152 & 153.3 \\
\hline & DBP HBI, mm Hg / h & 50 & 9 & 85.3 & 81 & 57 & 101.3 \\
\hline \multirow[t]{6}{*}{ Sleep- time } & SBP, mm Hg & 130 & 126 & 22.0 & 138 & 141 & 13.9 \\
\hline & DBP, mm Hg & 74 & 71 & 11.0 & 78 & 76 & 10.6 \\
\hline & SBP TI, \% & 55 & 60 & 31.4 & 79 & 95 & 28.5 \\
\hline & DBP TI, \% & 49 & 43 & 34.4 & 63 & 64 & 33.9 \\
\hline & SBP HBI, mm Hg / h & 97 & 42 & 143.9 & 133 & 118 & 94.3 \\
\hline & DBP HBI, mm Hg / h & 51 & 31 & 56.7 & 63 & 35 & 60.0 \\
\hline \multicolumn{2}{|c|}{ Sleep-time relative SBP decline, \% } & 3 & 4 & 5.5 & 0 & 1 & 5.4 \\
\hline \multicolumn{2}{|c|}{ Sleep-time relative DBP decline, $\%$} & 5 & 7 & 7.0 & 4 & 5 & 4.0 \\
\hline
\end{tabular}

$M$ - mean value, Me - median, Sd-standard deviation, SBP-systolic blood pressure, DBP-diastolic blood pressure, $T I$ - time index, HBI - hyperbaric index

AH control in patients with insufficient degree of DBP decline in groups 1

Table 2 and 2 at the beginning and at the end of observation

\begin{tabular}{|l|c|c|c|c|}
\hline \multirow{2}{*}{ Parameters } & \multicolumn{2}{|c|}{ Group 1 } & \multicolumn{2}{c|}{ Group 2 } \\
\cline { 2 - 5 } & visit 1 & visit 2 & visit 1 & visit 2 \\
\hline Controlled AH & $29 \%$ & $33 \%$ & $14 \%$ & $25 \%$ \\
\hline Nocturnal AH & $71 \%$ & $66 \%$ & $86 \%$ & $75 \%$ \\
\hline
\end{tabular}

The ABPM indices in patients with insufficient degree of DBP decline after 3 months in comparison to initial data are represented in table 3 . Overall, we achieved a reduction of all ABPM parameters and target values of SBP and DBP for all monitoring periods, except sleep-time DBP, which have been reduced, but did not normalize.
Statistically significant differences at the level of $p<0.05$ were achieved for sleep-time means of DBP, DBP TI and DBP HBI. The sleep-time relative SBP decline improved insignificantly in comparison to initial data, while the sleep-time relative DBP decline was not only improved but normalized with significant differences at the level of $\mathrm{p}<0.05$ (tab. 3). 
Comparison of the main ABPM indices in patients with insufficient degree of DBP decline at visits 1 and 2

\begin{tabular}{|c|c|c|c|c|c|c|c|}
\hline \multirow{3}{*}{$\begin{array}{l}\text { Monitoring } \\
\text { periods }\end{array}$} & \multirow{3}{*}{ ABPM indices } & \multicolumn{6}{|c|}{ Visits } \\
\hline & & \multicolumn{3}{|c|}{ visit 1} & \multicolumn{3}{|c|}{ visit 2} \\
\hline & & M & Me & Sd & $\mathbf{M}$ & Me & Sd \\
\hline \multirow[t]{6}{*}{24 hours } & SBP, mm Hg & 136 & 132 & 20.3 & 127 & 127 & 11.4 \\
\hline & DBP, mm Hg & 79 & 76 & 11.6 & 73 & 76 & 7.1 \\
\hline & SBP TI, \% & 52 & 52 & 33.7 & 37 & 38 & 27.6 \\
\hline & DBP TI, \% & 40 & 30 & 32.3 & 22 & 12 & 21.7 \\
\hline & SBP HBI, mm Hg / h & 267 & 161 & 330.6 & 125 & 115 & 125.0 \\
\hline & DBP HBI, mm Hg / h & 129 & 55 & 150.3 & 44 & 28 & 45.2 \\
\hline \multirow[t]{6}{*}{ Awake } & SBP, mm Hg & 137 & 131 & 21.0 & 129 & 126 & 13.1 \\
\hline & DBP, $\mathbf{m m ~ H g}$ & 80 & 76 & 11.8 & 75 & 77 & 7.5 \\
\hline & SBP TI, \% & 46 & 36 & 36.4 & 28 & 16 & 30.1 \\
\hline & DBP TI, \% & 33 & 18 & 33.4 & 20 & 14 & 17.3 \\
\hline & SBP HBI, mm Hg / h & 152 & 49 & 214.4 & 63 & 28 & 111.7 \\
\hline & DBP HBI, mm Hg / h & 65 & 19 & 93.3 & 26 & 26 & 17.2 \\
\hline \multirow[t]{6}{*}{ Sleep- time } & SBP, mm Hg & 134 & 131 & 18.4 & 124 & 129 & 9.9 \\
\hline & DBP, mm Hg & $76^{*}$ & 73 & 10.9 & $67 *$ & 65 & 7.9 \\
\hline & SBP TI, \% & 67 & 70 & 31.9 & 53 & 67 & 36.5 \\
\hline & DBP TI, \% & $56^{*}$ & 56 & 34.3 & $26^{*}$ & 12 & 33.7 \\
\hline & SBP HBI, mm Hg / h & 115 & 77 & 120.8 & 62 & 85 & 42.2 \\
\hline & DBP HBI, mm Hg / h & $57 *$ & 31 & 57.6 & $18 *$ & 3 & 31.6 \\
\hline \multicolumn{2}{|c|}{ Sleep-time relative SBP decline, \% } & 2 & 3 & 5.5 & 3 & -1 & 8.6 \\
\hline \multicolumn{2}{|c|}{ Sleep-time relative DBP decline, \% } & $5^{*}$ & 6 & 5.6 & $10 *$ & 13 & 7.7 \\
\hline
\end{tabular}

$M$ - mean value, Me - median, $S$ - standard deviation, SBP - systolic blood pressure, DBP - diastolic blood pressure, TI - time index, HBI-hyperbaric index* $p<0.05$

The ABPM indices in patients with insufficient degree of DBP decline in groups 1 and 2 after 3 months are represented in table 4 . At the second visit in group 1 daily and awake SBP and DBP target values were achieved, while sleep-time SBP and DBP means normalization was failed though its decline was achieved. In group 2 at the second visit decline and normalization of target SBP and DBP values were achieved during all the periods of observation except sleep-time related SBP decline. In group 1 the values of SBP HBI have declined in comparison to initial data and the mean awake-time values of SBP HBI were normalized. Mean daily values and mean awake-time values of DBP were nearly unchanged and the sleep-time DBP values have even improved. In group 2 the SBP HBI values decline was achieved and DBP HBI values were restored to borderline or normal levels.
The changes of daily SBP and DBP profile in patients with insufficient degree of DBP decline in groups 1 and 2 after 3 months are given in table 5 . The normalization of daily SBP profile in group 1 was achieved in $2 / 3$ of patients. At the second visit in group 2 the improvement of sleep-time relative SBP decline was achieved but the normalization of daily SBP profile wasn't in any patient of this group (tab. 4, 5).

The types of daily DBP profile (dipper, nondipper and overdipper) distributed evenly between all patients in group 1 at the second visit (tab. 5). In the group 2 the values of sleep-time relative DBP decline were adjusted in accordance with dipper type: the normalization of daily DBP profile was observed in a half of patients of this group (tab. 4, 5). In both groups at the second visit the number of patients with nocturnal $\mathrm{AH}$ was decreased while the percent of patients with controlled $\mathrm{AH}$ was increased. These 
changes are more significant in the group 2 (tab. 2).

There were no statistically significant differences in group 1 between first and second visit. In group 2 statistically significant decrease of sleep-time DBP values and sleep-time relative DBP decline in comparison to initial data at the level of $\mathrm{p}<0.05$ was achieved along with decrease of sleep-time values of DBP HBI at the level of $\mathrm{p}<0.01$ (tab. 4).

Table 4

ABPM indices in patients with insufficient degree of DBP decline in groups 1 and 2, visit 2

\begin{tabular}{|c|c|c|c|c|c|c|c|}
\hline \multirow{3}{*}{$\begin{array}{l}\text { Monitoring } \\
\text { periods }\end{array}$} & \multirow{3}{*}{ ABPM indexes } & \multicolumn{6}{|c|}{ Patients groups } \\
\hline & & \multicolumn{3}{|c|}{ group 1} & \multicolumn{3}{|c|}{ group 2} \\
\hline & & $\mathbf{M}$ & Me & Sd & M & Me & Sd \\
\hline \multirow[t]{6}{*}{24 hours } & SBP, mm Hg & 126 & 127 & 1.2 & 128 & 126 & 16.0 \\
\hline & DBP, mm Hg & 78 & 76 & 4.0 & 70 & 69 & 7.0 \\
\hline & SBP TI, \% & 29 & 38 & 15.1 & 43 & 39 & 35.6 \\
\hline & DBP TI, \% & 34 & 37 & 29.5 & 13 & 11 & 10.8 \\
\hline & SBP HBI, mm Hg / h & 78 & 107 & 58.1 & 160 & 121 & 158.9 \\
\hline & DBP HBI, mm Hg / h & 67 & 58 & 66.9 & 26 & 24 & 13.5 \\
\hline \multirow[t]{6}{*}{ Awake } & SBP, $\mathrm{mm} \mathrm{Hg}$ & 126 & 126 & 2.5 & 130 & 125 & 18.2 \\
\hline & DBP, mm Hg & 80 & 78 & 3.8 & 72 & 71 & 8.5 \\
\hline & SBP TI, \% & 17 & 16 & 3.2 & 36 & 20 & 40.0 \\
\hline & DBP TI, \% & 25 & 27 & 22.0 & 16 & 10 & 15.1 \\
\hline & SBP HBI, mm Hg / h & 19 & 19 & 9.1 & 96 & 30 & 146.5 \\
\hline & DBP HBI, mm Hg / h & 27 & 28 & 25.3 & 25 & 22 & 12.8 \\
\hline \multirow[t]{6}{*}{ Sleep- time } & SBP, mm Hg & 126 & 129 & 8.5 & 122 & 125 & 11.9 \\
\hline & DBP, mm Hg & $74 *$ & 71 & 8.3 & $63 *$ & 64 & 3.2 \\
\hline & SBP TI, \% & 51 & 67 & 40.7 & 55 & 65 & 39.4 \\
\hline & DBP TI, \% & 49 & 52 & 44.0 & 9 & 11 & 6.0 \\
\hline & SBP HBI, mm Hg / h & 60 & 88 & 49.8 & 63 & 77 & 43.6 \\
\hline & DBP HBI, mm Hg / h & 39 & 30 & 42.0 & $2 * *$ & 2 & 1.1 \\
\hline \multicolumn{2}{|c|}{ Sleep-time relative SBP decline, \% } & 7.5 & 10 & 11.5 & 6 & 4 & 9.2 \\
\hline \multicolumn{2}{|c|}{ Sleep-time relative DBP decline, \% } & 8 & 8 & 6.8 & $12^{i}$ & 13 & 8.7 \\
\hline
\end{tabular}

$M$ - mean value, $M e$ - median, Sd - standard deviation, SBP - systolic blood pressure, DBP-diastolic blood pressure, TI - time index, HBI - hyperbaric index; ${ }^{*} p<0,05$ comparing groups 1 and 2 at visit 2; ${ }^{i} p<0,05$ comparing visits 1 and 2 of group $2 ;{ }^{* *} p<0,01$ comparing visits 1 and 2 of group 2 .

In group 2 the SBP and DBP levels in all periods of monitoring were reduced to a greater extent than in group 1. Particularly, the mean daily and awake relative DBP values are increased in comparison to the first visit though they still remain within the normative values. The mean sleep-time relative DBP values stay unchanged.

The lower values of DBP ABMP indices at the second visit were achieved in group 2 . In group 1 the lower values of ABMP indices at the second visit were noticed in parameters that refer to SBP.
Sleep-time relative SBP decline increased approximately equally in groups 1 and 2 $(+4.5 \%$ and $+5.6 \%$ respectively) (tab. 1,4$)$. The normalization of daily SBP profile in group 1 was achieved in 2/3 of patients while in group 2 its normalization was achieved in none of the patients (tab. 5).

Sleep-time relative DBP decline increased more in group 2 in comparison to group 1 $(+8 \%$ and $+3 \%$ respectively) (tab. 1,4$)$. The normalization of daily DBP profile was achieved in most of patients in group 2. In group 1 the daily DBP profile changed to overdipper type in $1 / 3$ of patients (tab. 5). 
BP daily profiles in patients with insufficient degree of DBP decline in groups 1 and 2 at the first and second visits

\begin{tabular}{|c|c|c|c|c|c|}
\hline \multirow{2}{*}{\multicolumn{2}{|c|}{ Daily profile type }} & \multicolumn{2}{|c|}{ Group 1} & \multicolumn{2}{|c|}{ Group 2} \\
\hline & & \multirow{2}{*}{$\begin{array}{c}\text { visit } 1 \\
0\end{array}$} & \multirow{2}{*}{$\begin{array}{c}\text { visit } 2 \\
67 \%\end{array}$} & \multirow{2}{*}{$\begin{array}{c}\text { visit } 1 \\
0\end{array}$} & \multirow{2}{*}{$\begin{array}{c}\text { visit } 2 \\
0\end{array}$} \\
\hline SBP & dipper & & & & \\
\hline & nondipper & $100 \%$ & $33 \%$ & $100 \%$ & $100 \%$ \\
\hline & overdipper & 0 & 0 & 0 & 0 \\
\hline \multirow[t]{3}{*}{ DBP } & dipper & 0 & $33 \%$ & 0 & $50 \%$ \\
\hline & nondipper & $100 \%$ & $33 \%$ & $100 \%$ & $50 \%$ \\
\hline & overdipper & 0 & $33 \%$ & 0 & 0 \\
\hline
\end{tabular}

\section{DISCUSSION}

The change in the paradigm of the importance of $\mathrm{DBP}$ as a risk factor for $\mathrm{CV}$ events in the late 90s of the last century led to the fact that in the overwhelming majority of cases only the daily SBP profiles are estimated $[4,5]$ and very little attention is given to daily DBP profiles [6].

We also did not find studies on the effect of AH chronotherapy on the daily DBP profile.

The obtained data show that the morning intake of antihypertensive drugs in patients with $\mathrm{AH}$ with insufficient degree of sleeptime relative DBP decline has a greater impact on SBP, and the evening intake - on DBP, which can be explained by differences in the mechanisms of their regulation [7].

In accordance with this, it is not enough to focus only on the daily SBP profile in the treatment of patients with $\mathrm{AH}$.

\section{CONCLUSIONS}

1. The antihypertensive therapy in patients with insufficient degree of sleep-time relative DBP decline, regardless of the regimen of medications, leads to SBP and DBP levels decrease with normalization of their daily profiles.

2. The results of the therapy depend on the time of antihypertensive drugs intake, and the morning reception reduces the SBP to a greater extent, and the evening one-DBP.

3. In the pharmacotherapy of patients with $\mathrm{AH}$ with insufficient degree of sleep-time relative DBP decline, the assessment of its daily profile should be carried out along with the daily SBP profile.

\section{PROSPECTS FOR FUTURE STUDIES}

It seems advisable to compare the effects of chronotherapy in patients with insufficient degree of sleep-time relative SBP decline and patients with insufficient degree of sleep-time relative DBP decline.

\section{REFERENCES}

1. European Society of Hypertension practice guidelines for ambulatory blood pressure monitoring / [G. Parati, G. Stergiou, E. O'Brien et al.]. // Journal of Hypertension. - 2014. - Vol. 32(7). - P. 13591366.

2. $2013 \mathrm{ESH} / \mathrm{ESC}$ Guidelines for the management of arterial hypertension: The Task Force for the management of arterial hypertension of the European Society of Hypertension (ESH) and of the European Society of Cardiology (ESC) // Journal of Hypertension. - 2013. - Vol. 31, Is. 7. - P. 1281-1357.

3. Prognostic Effect of the Nocturnal Blood Pressure Fall in Hypertensive Patients: The Ambulatory Blood Pressure Collaboration in Patients With Hypertension (ABC-H) Meta-Analysis. / [G. F. Salles, G. Reboldi, R. H. Fagard et al.]. // Hypertension. - 2016. - Vol.67. - P. 693-700.

4. Heart rate variability in patients with hypertension, comorbid with peptic ulcer disease, taking into account circadian systolic blood pressure / [O. E. Tomina, O. Y. Bichkova, G. M. Fomych et al.]. // The journal of V. N. Karazin` KhNU, Series «Medicine». - 2012. - Issue 24. - P. 52-62. 
5. Efficacy of cormobid octeoarthrosis with arterial hypertension control considering the types of orthostatic reactions and circadian profiles of arterial pressure / I. V.Soldatenko, N. V. Lysenko, O. E. Tomina, V. L. Kulyk. // The journal of V. N. Karazin` KhNU, Series «Medicine». - 2013. - Issue 25. - P. 47-53.

6. Ambulatory Hypertension Subtypes and 24-Hour Systolic and Diastolic Blood Pressure as Distinct Outcome Predictors in 8341 Untreated People Recruited From 12 Populations / [Yan Li, Fang-Fei Wei, Lutgarde Thijs et al.]. // Circulation. - 2014. - Vol. 130. - P. 466-474.

7. O’Rourke M. Mechanical principles in arterial disease / O’Rourke. // Hypertension. - 1995. - Vol. 26. P. 2-9.

8. Single versus combined blood pressure components and risk for cardiovascular disease: the Framingham Heart Study / [S. S. Franklin, V. A. Lopez, N. D. Wong et al.]. // Circulation. - 2009. - Vol. 119. P. 243-250.

9. Petrenko O. V. The effectiveness of chronotherapy in hypertensive patients with an insufficient degree of sleep-time systolic blood pressure decline / O. V. Petrenko, M. I. Yabluchansky. // The journal of V. N. Karazin`KhNU, Series «Medicine». - 2017. - Vol. 34. - P. 19-26.

10. 2013 ambulatory blood pressure recommendations for the Diagnosis of Adult Hypertension, Assessment of Cardiovascular and other Hypertension-associated Risk and Attainment of Therapeutic Goals // Chronobiology International. - 2013. - Vol. 30 (3). - P. 355-410. 